\title{
INDICATORS FOR ECONOMIC CORRIDOR DEVELOPMENT: AN APPROACH FROM INFRASTRUCTURE OPERATION AND SERVICES PERFORMANCE INDICATOR
}

\author{
I GW Samsi Gunarta ${ }^{1 *}$, Wimpy Santosa ${ }^{2}$, Anastasia Caroline Sutandi ${ }^{3^{*}}$ \\ Faculty of Engineering, Universitas Katolik Parahyangan, Bandung, Indonesia ${ }^{1,2,3}$
}

\begin{abstract}
The concept of economic corridor was introduced to be a breakthrough in the acceleration of economy development of the designated areas. The success of an economic corridor to grow further is determined by the performance of infrastructure, corridor services, and management of the corridor. The study aims at explaining the concept and process development of assessment tools to identify the service readiness and performances of Infrastructure to support development progress of corridors. A desk study has been conducted to identify parameters of measurements using public, government, and user views that might apply to Indonesian Economic Corridor. All parameters and indicators were selected on the basis of supply performances, quality of services, efficiency, utilization, and sustainability of the infrastructure. The study results in 9 outcomes and 31 infrastructure services indicators to be used in measuring corridor performance in relation infrastructure operations of the corridor. This only one side of the corridor performance assessment process but would be one of two important steps to able to assess the performance of Indonesian Economic Corridor grow beyond.
\end{abstract}

Keywords: $\quad$ Economic Corridor, Corridor Performance, Spatial Initiatives

\section{Introduction}

Corridor development as part of Spatial Development Initiative (SDI) have been widely introduced to enable faster economic development. Indonesia has adopted the concept as part of the Master Plan for Acceleration and Expansion of Indonesia Economic Development (MP3EI) forming 6 Thematic-National Wide (Zone 2) corridor that lay over major islands of Indonesia. Theoretically, the benefit of corridor concept in accelerating economy development would be determined from the performance of infrastructure, corridor services, and management of the corridor, which interact between each others that performs corridor operation, planning integration process, and well managed standards and regulations.

Infrastructure is major determinant influencing the performance of Corridor. The parameter that is used to measure infrastructure related performances includes the operation of infrastructure in relation to accessibility and capacity, service quality, efficiency, and its utilization. Based on ability of corridor to perform services on transport and logistic, production, accommodating certain living standards, and managing risks and sustainable development, a corridor then progressing their development stage.

In a number of studies, measurement upon corridor performance have been conducted in many different ways. To certain stages it is apparent that infrastructure performances has been used as tools of measurement. However, due to nature of corridor program that focuses more upon economic growth, it is appear that infrastructure performance also emphasized for transport and logistics support and productions. A number of important parameters to enable continuing growth of corridors seems to be overlooked. This study, therefore attempts to discover important parameters and indicators to be applied in promoting corridor development. This is a preliminary study to scan potential indicators in relation to infrastructure services that should be provided to enable a corridor grow beyond transport corridor. Review upon a number of corridor and 
International Journal of Economics, Business, and Accounting Research (IJEBAR)

Peer Reviewed - International Journal

Vol-5, Issue-1, 2021 (IJEBAR)

E-ISSN: 2614-1280 P-ISSN 2622-4771

https://jurnal.stie-aas.ac.id/index.php/IJEBAR

infrastructure performance yields in a set of measurement indicators in relation to infrastructure operation and integrated planning.

\section{Understanding a corridor and its basic features}

A corridor is defined as a narrow area lays along a backbone infrastructure that has economic potential to grow. It is characterized by the development of center of economic activities and services [7]. Some differentiate corridor on the basis of it size and its thematic development. Size of corridors may vary following the need for connection that is considered to be effective in to make significant improvement in logistics movement as basic support to production improvement and economic growth. Based on its size, a transportation corridor can be categorized into, national-narrow (Zone I), national-broad (Zone II), regional-narrow (Zone III), or regional-broad (Zone IV) corridor [19]. While in relation to development progress a corridor categorized as transport corridor, multimodal corridor, logistics corridor, economic corridor, and growth corridor $[2,14]$

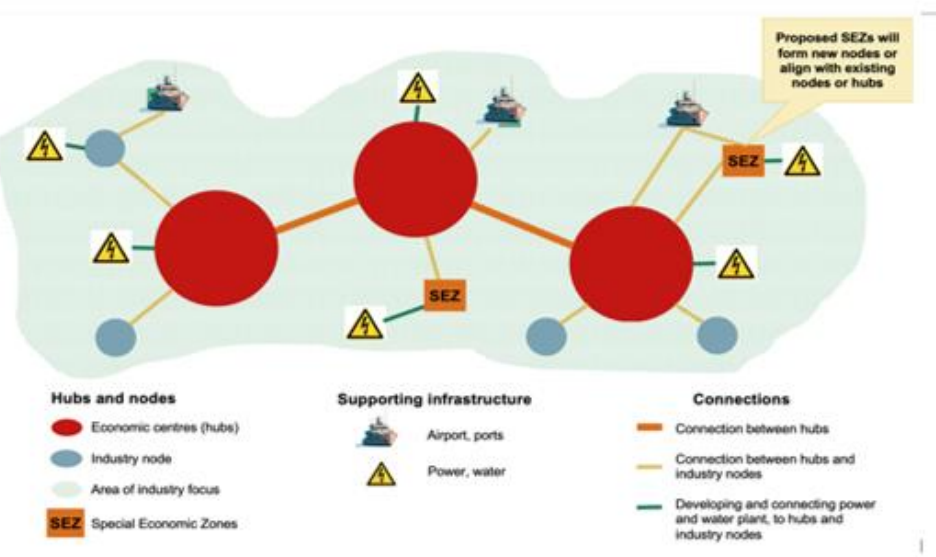

Source: [3]

Fig. 1 - Concept of Economic Corridor

Srivastava [19] highlighted the importance of zonal category as it is closely related to focuses of corridor development and interests of initiating organization. International organizations, such as Asian Development Bank or the World Bank, initiated a number of regional corridors in association with effort in promoting more efficient logistics and even growth opportunities between countries. Others initiator, can be national government or a bilateral cooperation, develop corridor program in association with a need for better transportation and logistics distribution, to support a more efficient production as well as improving local environment and quality of life [14].

As a Spatial Development Initiative (SDI) a corridor is established to sort out planning problems that is characterized by the tendency of internal strengthening of growth poles that may cause adverse economy attraction between poles. This would also answer the hierarchical and rigid planning process that blocks smooth integration between stakeholders [17]. Normally, the commitment of corridor started with mutual understanding between governments, national government or regional organizations to provide and utilize infrastructure as common needs in 
accommodating productivity and economic growth $[5,15]$. This has transformed the orientation of infrastructure services and development to productivity rather than spreading the service of the infrastructure. As a consequence, large service capacity of infrastructure is dedicated to support the development of production areas and the spill would be used for the surrounding areas. Therefore, strong coordination and good communication to enable balance support to corridor investment in any sectors are required.

In association with activities that characterised a corridor, there are a number of thematic corridor have been introduced. Indonesia, with respect to the Presidential Regulation no 32 year 2011, associate Indonesia Economic Corridor with major activities and commodities that is expected to support future competitiveness of the nation [3]. Out of 6 economic corridors which are planned to become pillars of Competitiveness of Indonesia in 2050, a number of themes of corridors were introduced, namely Industrial, Agro-Industry, Tourism and Fisheries, and Energy and mining industry corridor. India has also developed a well-known Delhi-Mumbai Industrial Corridor (DMIC). These themes, more likely to exhibit focused sectors that is expected to be major-economic driver in the future. Accordingly, infrastructure, services, and regulations, within the corridor should be adjusted accordingly.

\section{Stages of Development and Performance of a corridor}

Banomyong [2] divides the transformation progress of corridor into 4 (four) stages, namely, transportation corridor, multimodal corridor, logistics corridor, and economic corridor. Other researcher [14] categorized the transformation process into transportation corridor, logistics corridor, economic corridor, and growth corridor. In early stage of corridor development, it is characterized by physical connection of transport infrastructures that is followed services for either passenger or freight transport. At this stage, it is named as Transport Corridor, wherein coordination in logistics that allows for a measurable performance in delivery, including well scheduled shipping as well as trace and track, does not exist. A transport corridor then is transformed to a Logistics Corridor. In a Logistics Corridor, the coordination between infrastructure, services, and institutional arrangement leads to efficient and competitive logistic system. Being economic corridor, production estates required to their accommodation toward wider investment areas, including incubating SMEs and start-up companies, to complement main investors of the corridor that create better synergy as an economy clusters. Eventually activity of economic corridor would lead to a growth corridor which integrates high quality livings with economic activities. The demand for infrastructure services within the progress of corridor development would have to be supplied in accordingly. The transformation process is exhibited by Nogales [14] in Fig. 2.

Examples of success story of corridors that completely growth includes the Northeast Corridor, or well known as Boston-Washington Corridor [9], and Tokaido (Tokyo-Osaka) Corridor [21]. Other corridors that showed positive progress are Alameda Corridor-California, Greater Mekong Sub-Corridor, Maputo Corridor, and West African Corridor [5, 12, 17, 20] . Despite the contradictory in socio-economic and uneven quality of life of the corridor due to wide coverage of the corridor [9, 21], NEC and Tokaido can be considered to be examples of excellent corridor development wherein transport infrastructures have brings in gradual development from transportation to economy and ultimately becoming a modern living environment $[9,13,21]$. 
International Journal of Economics, Business, and Accounting Research (IJEBAR)

Peer Reviewed - International Journal

Vol-5, Issue-1, 2021 (IJEBAR)

E-ISSN: 2614-1280 P-ISSN 2622-4771

https://jurnal.stie-aas.ac.id/index.php/IJEBAR

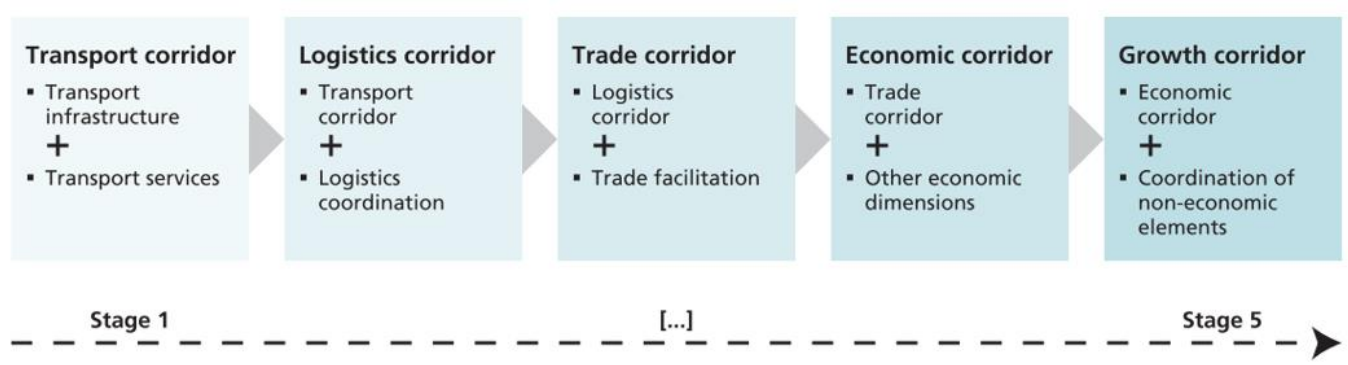

Source: [14]

Fig. 2 - Stages in Corridor Development

As part of Spatial Development Initiative (SDI), a corridor development program usually involves synergy between 3 basic features, namely Infrastructure, transportation and logistics services, and institutional establishment [7]. As it has been done in many regional corridor programs, Infrastructure development was taken to be triggering project then followed by establishing a corridor management, and systematically improve transport and logistic services, as well as improving investment atmosphere in association with corridor activity. Consequently, the Evaluation upon the effectiveness of a corridor program also considers the progress of these basic features as major parameter $[4,16]$

Kunaka and Charruthers [7] illustrates corridor performance as an inter-relation between infrastructure, institution, and services in Fig. 3. Parameters to measure within the inter-relation include corridor operations, planning integration, and standards and regulations. Corridor Operations to be concerned would consist of Integration of intra services, Access for Third Party, and Interoperability between sub systems. In Planning integrations, concerned matters would include Infrastructure Priority, Area Interconnection, and Infrastructure Investment, while Standards and regulations require to establish would include Access Rights, Transit Regime, and Service Contracts. This model brings in ideas how corridor performance would be measured and determined whether or not the corridor is going to be effectively support economic growth.

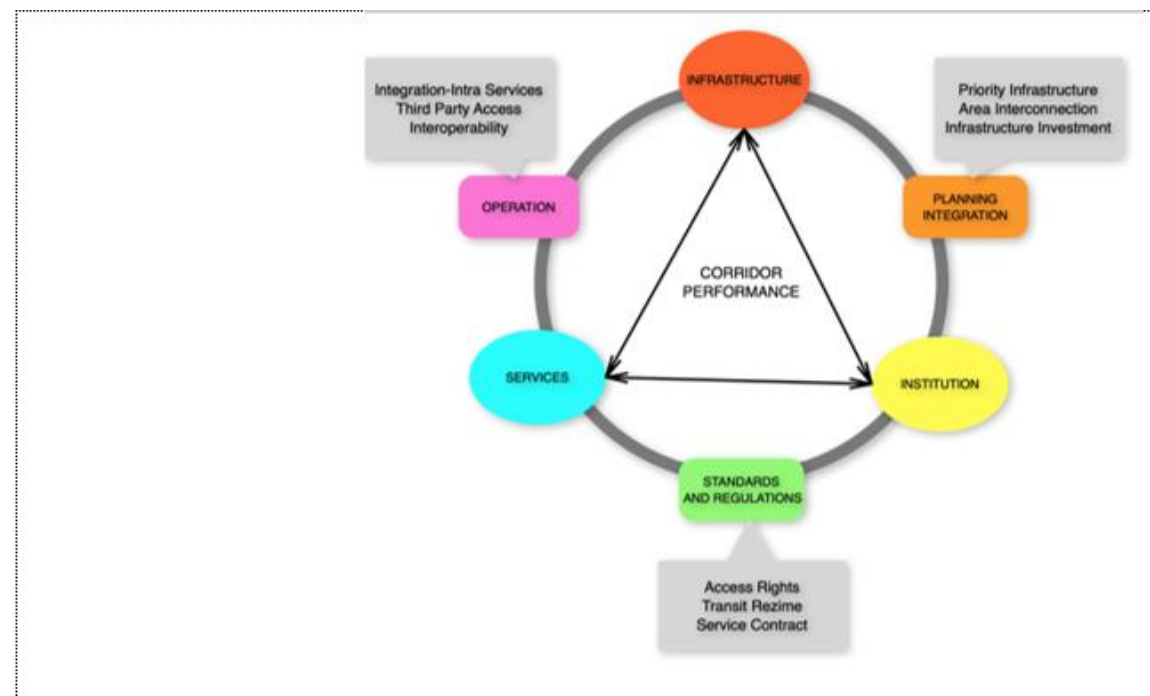

Source: [7] 
International Journal of Economics, Business, and Accounting Research (IJEBAR)

Peer Reviewed - International Journal

Vol-5, Issue-1, 2021 (IJEBAR)

E-ISSN: 2614-1280 P-ISSN 2622-4771

https://jurnal.stie-aas.ac.id/index.php/IJEBAR

Fig. 3 - Model of Corridor Performance

\section{Concept and Indicator uses in Assessing Corridor Performance from its infrastructure Services}

Effectiveness of a corridor has been measured from a variation of approach. Since large numbers of parameters relates to the availability and reliability of infrastructure, it can be said that infrastructure performance can be a good predictor for Corridor Performance. Infrastructure interacts with other determinants of corridor through two parameters, namely the success of planning integration dan corridor operation and services [7]. Some researcher found the idea to look at the output of infrastructure project have never given a good indication of the outcomes of the project. McNeil et al [8], therefore, suggested to measure output performance of the infrastructure project in addition to the output. This makes it clear that infrastructure, in association with its operation and service performances in the corridor, would be a potential measurement tools to see whether or not a corridor would be effectively functioning and heading toward its next stage of transformation.

The use of Infrastructure Performance Indexes to see Performance of supply, Quality of Services, Efficiency, and Utility in assessing the performance of infrastructure was conducted by McNeil et al [8]. The study applied for metropolitan areas that showed the performance of Metropolitan Services Areas (MSAs) and rate the status of services of the infrastructure. This idea provides better views upon reliability, worthiness, value for money, and potential growth of infrastructure uses. This concept would be also applicable for that of corridor infrastructure performance to show readiness of infrastructure in connecting corridor's elements, supporting productivity, supporting quality of life, and ensuring the harmony of economic activity, social lives, and the environment. Fig 4 is the concept developed in applying McNeil's method to exhibit how infrastructure performance could indicate progress of development of a corridor through its infrastructure services.

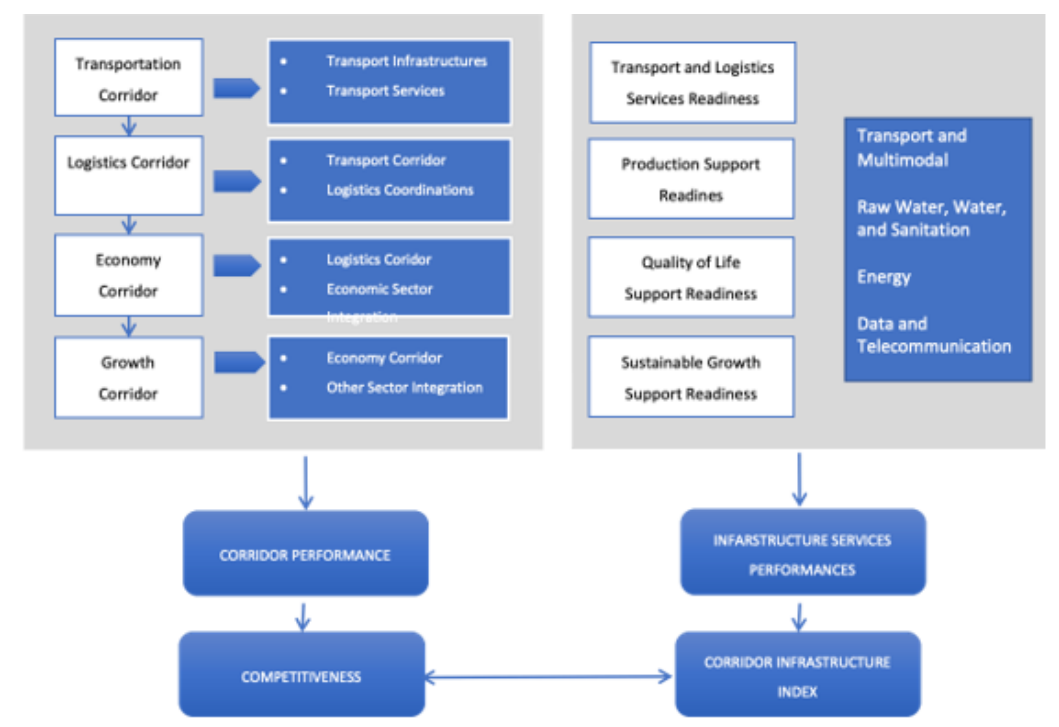

Fig. 4 - Conceptual Model of Corridor and Infrastructure Performance

The process of indicator selection to enable the assessment of infrastructure services is shown in Fig. 5. A 4-steps selection has been conducted to provide a comprehensive set of infrastructure services indicators to meet the concept exhibited in Fig. 4. Step 1 includes making 
inventory of indicators. There are 11 research papers found relevant and having specific concerns upon the need of corridor infrastructure using various different perspectives. They suggested indicators to be used in assessing corridor performance. The perspectives used include perspectives, users, government, and the general public [1, 5, 7], policy makers [4] micro and macroeconomic perspectives [18] ; service reliability perspective $[8,16]$ and sustainable supply chain [15]. Of these, 191 indicators were identified including the parameters of supply performance, service quality, efficiency and utilization as well as risk control and sustainability.

Step 2 includes numerically coding every indicators to detect typical and potentially corelated indicators which can be seen from the code numbers. This step results in 164 indicators, which are considered to be non-identical. Step 3 then regrouped the indicators to 6 different slots, namely (1) general performance indicator, (2) outcome indicator, (3) Transport and Logistics Services Indicators, (4) Production support Indicators, (5) Quality of life support indicators, and (6) Sustainable Growth Indicators. There are 60 indicators found relevant related to these slots from 3 elements of corridor performance. After such process, a number of indicators in relation to institution performances were filtered to make the set suits the context of the research. From the whole process 44 indicators were yielded in, and 31 out of those were associated with infrastructures and its operations.

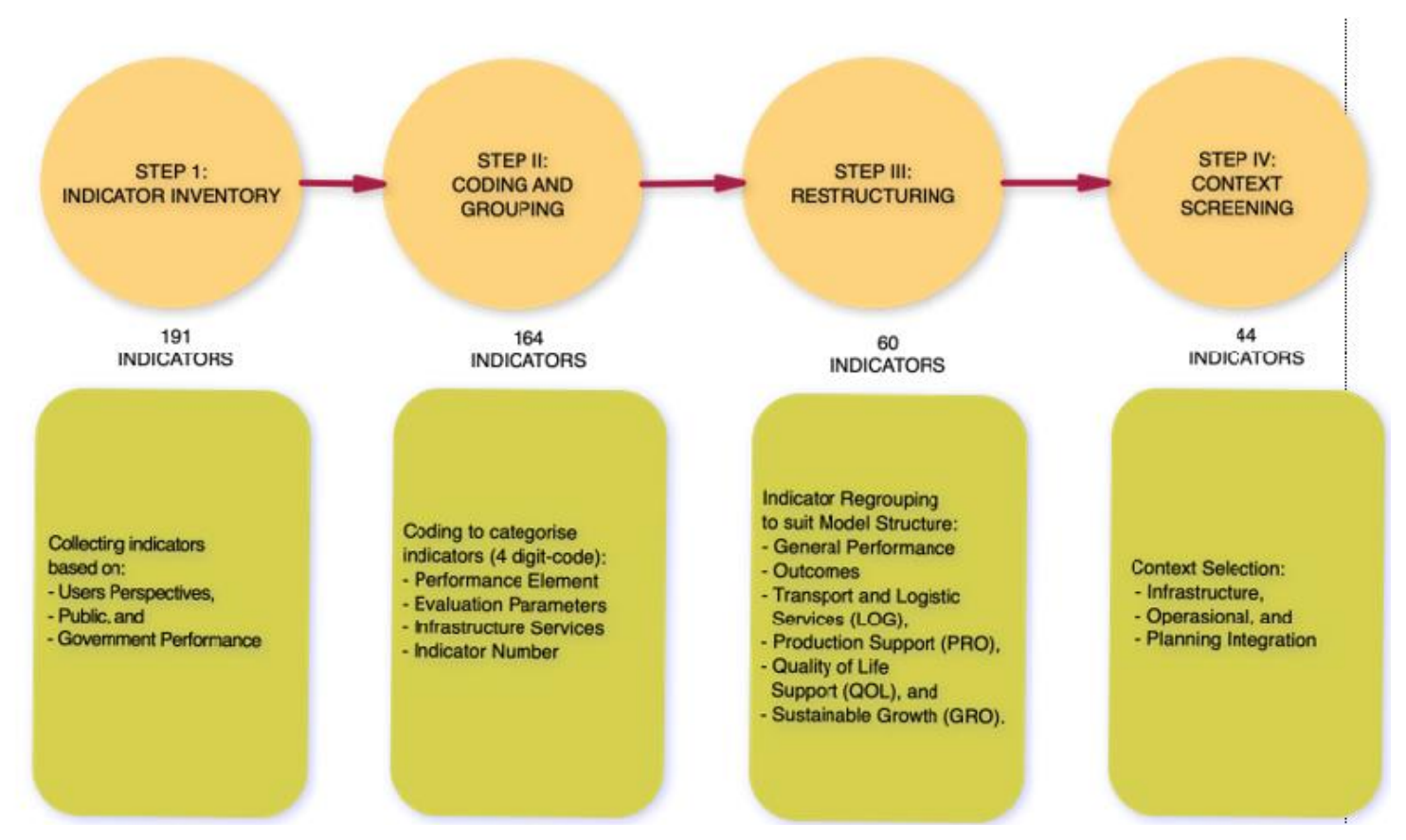

Fig. 5 - Indicator Selection Process

\section{Results}

Through a 4 steps selection process, including, regrouping, coding, and screening similar indicator based on research context, 31 indicators in relation to infrastructure services were found. The set consist of 12 indicators of transportation and logistic services (LOG), 6 indicators of production support (PRO), 7 indicators for services of quality of life (QOL), and 6 indicators of sustainable growth (GRO). Corridor that is able to perform these services can be predicted to develop sustainably and provide sufficient support to economic development and acceleration. 
International Journal of Economics, Business, and Accounting Research (IJEBAR)

Peer Reviewed - International Journal

Vol-5, Issue-1, 2021 (IJEBAR)

E-ISSN: 2614-1280 P-ISSN 2622-4771

https://jurnal.stie-aas.ac.id/index.php/IJEBAR

\subsection{Transport and Logistics Readiness}

The screening process against indicators that is collected from previous researchers resulted in 12 services. These indicators are considered to be influencing factors in determining transport and logistics performance that can drive corridor to grow further. They consist of availability and performance of these services would describe soundness of connectivity and quality of Infrastructure, modal reliability, scope and quality of services, efficiency, utilization, and risks control in logistics and transportation. Infrastructures which are related to logistics and transportation performance of a corridor include transport backbone, alternative transport mode and intermodal facility, ports, safety infrastructure, and high-speed internet services.

Table 1 - Performance Indicators of Transport and Logistic Services

\begin{tabular}{|c|c|c|c|}
\hline No & Services & Indicator & $\begin{array}{l}\text { Reference } \\
\text { S }\end{array}$ \\
\hline 1 & $\begin{array}{l}\text { Backbone } \\
\text { Connectivity }\end{array}$ & $\begin{array}{l}\text { Percentage of Corridor's major } \\
\text { elements within } 50 \mathrm{~km} \text { distance } \\
\text { connected to the Backbone }\end{array}$ & {$[5,7,8]$} \\
\hline 2 & Alternative Mode & Ton $\mathrm{Km} /$ Year & {$[4,8]$} \\
\hline 3 & $\begin{array}{l}\text { Intermodal } \\
\text { Facility }\end{array}$ & Ton/Year; TEUs/Year & {$[1,4,7]$} \\
\hline 4 & $\begin{array}{l}\text { Safety } \\
\text { Infrastructure }\end{array}$ & $\begin{array}{l}\text { Availability of Traffic and } \\
\text { Navigation Control Facility }\end{array}$ & {$[7,15]$} \\
\hline 5 & $\begin{array}{l}\text { Port-Services } \\
\text { Capacity }\end{array}$ & Hour per Ton or Hour per TEUs & {$[4,16]$} \\
\hline 6 & $\begin{array}{l}\text { Average Travel } \\
\text { Speed of } \\
\text { Backbone }\end{array}$ & $\begin{array}{l}\text { Percentage of Actual Travel time per } \\
100 \mathrm{kms}\end{array}$ & {$[4,16]$} \\
\hline 7 & $\begin{array}{l}\text { Penetration of IT } \\
\text { in Logistics }\end{array}$ & $\begin{array}{l}\text { Availability of IT Management to } \\
\text { support Track and Trace and } \\
\text { Electronic Data Exchange (EDI) }\end{array}$ & $\begin{array}{l}{[1,4,7,} \\
15]\end{array}$ \\
\hline 8 & Clearance Time & $\begin{array}{l}\text { Percentage of time compliance of } \\
\text { custom clearance process }\end{array}$ & $\begin{array}{l}{[1,4,7,} \\
15]\end{array}$ \\
\hline 9 & $\begin{array}{l}\text { Reliable } \\
\text { Alternative } \\
\text { Transpot Mode }\end{array}$ & $\begin{array}{l}\text { Timeliness of Alternative Transport } \\
\text { Mode }\end{array}$ & {$[15]$} \\
\hline 10 & $\begin{array}{l}\text { Transport Costs } \\
\text { Using Backbone }\end{array}$ & USD/Ton.Km & {$[4,15.12]$} \\
\hline 15 & $\begin{array}{l}\text { Transport Costs } \\
\text { of Alternative } \\
\text { Mode }\end{array}$ & USD/Ton.Km & {$[4,5]$} \\
\hline 16 & $\begin{array}{l}\text { Average } \\
\text { Utilisation of } \\
\text { backbone }\end{array}$ & V-C Ratio of Backbones & {$[7,15,16]$} \\
\hline
\end{tabular}


International Journal of Economics, Business, and Accounting Research (IJEBAR)

Peer Reviewed - International Journal

Vol-5, Issue-1, 2021 (IJEBAR)

E-ISSN: 2614-1280 P-ISSN 2622-4771

https://jurnal.stie-aas.ac.id/index.php/IJEBAR

\subsection{Production Support Readiness}

In a formally developed economic corridor, the provision of infrastructure services is designed to support the growth of corridor elements, such as industrial estates and special economic zones (SEZ) to ensure efficient production services. Important issues related to production support are the availability of raw water for production, the availability of clean industrial water, the availability of energy, and the availability of high speed internet and broadband services to enable smart production can be carried out. These issues would be great concerns because they determine the capacity of the production estates and required infrastructure for production support.

Table 2 - Performance Indicators of Production Support Readiness

\begin{tabular}{llll}
\hline No & Services & $\begin{array}{l}\text { Performance } \\
\text { Indicator }\end{array}$ & $\begin{array}{c}\text { Reference } \\
\text { S }\end{array}$ \\
\hline 1 & $\begin{array}{l}\text { Raw Water Supply for } \\
\text { Industry }\end{array}$ & m3/day & {$[8]$} \\
2 & Water Supply for Industry & $\begin{array}{l}\text { Percentage Serviced } \\
\text { area }\end{array}$ & {$[8]$} \\
3 & $\begin{array}{l}\text { Supply Capacity for } \\
\text { Electricity and Gas during } \\
\text { peak hours }\end{array}$ & $\begin{array}{l}\text { Percentage Serviced } \\
\text { Area }\end{array}$ & {$[8]$} \\
4 & $\begin{array}{l}\text { High Speed Internet and } \\
\text { Bandwidth Services for LoS }\end{array}$ & $\begin{array}{l}\text { Percentage Serviced } \\
\text { Area }\end{array}$ & {$[8]$} \\
& $\begin{array}{l}\text { 90\% } \\
\text { Utilisation of High Speed }\end{array}$ & $\begin{array}{l}\text { Percentage of MBPS } \\
\text { utilised }\end{array}$ & {$[8]$} \\
& $\begin{array}{l}\text { Internet } \\
\text { Development of large scale } \\
\text { production areas, Mining, }\end{array}$ & $\begin{array}{l}\text { Number of Estates } \\
\text { along the Corridor }\end{array}$ & {$[4]$} \\
& $\begin{array}{l}\text { Farming, Tourism, Industrial } \\
\text { Estate, or others }\end{array}$ & \\
\hline
\end{tabular}

\subsection{Quality of Life Support Readiness}

The growth of the population in settlement areas along the corridor become an important target for infrastructure services. This to ensure that the economy grows accordingly. In line with that, the development of new cities, either in the form of Transit Oriented Development (TOD), or cities that support industry is an opportunity that should not be ignored because of its feasibility and economies of scale. In addition, it can also encourage the availability of a more productive and sustainable living.

Services, that are predicted having strong influences on Quality of Life Support (QOL) includes settlement services and basic housing facilities. These include drinking water for domestic use, waste water, storm water and solid waste management. These infrastructures are basic infrastructures that contribute greatly in reducing the inefficiency of the community in providing live support and health as well as affecting comfort living. The extraction of several 
International Journal of Economics, Business, and Accounting Research (IJEBAR)

Peer Reviewed - International Journal

Vol-5, Issue-1, 2021 (IJEBAR)

E-ISSN: 2614-1280 P-ISSN 2622-4771

https://jurnal.stie-aas.ac.id/index.php/IJEBAR

previous studies results in 7 infrastructure services considered important to support the quality of life as presented in Table 3.

\begin{tabular}{|c|c|c|c|}
\hline No & Services & Performance Indicator & $\begin{array}{l}\text { Referenc } \\
\text { es }\end{array}$ \\
\hline 1 & $\begin{array}{l}\text { Domestic Water } \\
\text { Supply }\end{array}$ & $\begin{array}{l}\text { Percent Coverage of } \\
\text { Domestic Water supply }\end{array}$ & {$[8[$} \\
\hline 2 & $\begin{array}{l}\text { Quality of Water } \\
\text { Supply }\end{array}$ & $\begin{array}{l}\text { Percent coverage of potable } \\
\text { Water Suppy within the } \\
\text { service coverage }\end{array}$ & [8] \\
\hline 3 & $\begin{array}{l}\text { Utilisation of } \\
\text { Water }\end{array}$ & $\begin{array}{l}\text { Percentage Utilisation of } \\
\text { Water Supply System }\end{array}$ & [8] \\
\hline 4 & $\begin{array}{l}\text { Waste and Storm } \\
\text { Water } \\
\text { Management }\end{array}$ & $\begin{array}{l}\text { Coverage of Waste and } \\
\text { Storm Water Management } \\
\text { (Percent) }\end{array}$ & [8] \\
\hline 5 & $\begin{array}{l}\text { Low Cost } \\
\text { Housing }\end{array}$ & $\begin{array}{l}\text { Percentage of LHC } \\
\text { Available for Low Income } \\
\text { Worker }\end{array}$ & [11] \\
\hline 6 & $\begin{array}{l}\text { Independent Solid } \\
\text { Waste } \\
\text { Management }\end{array}$ & $\begin{array}{l}\text { Coverage of Solid Waste } \\
\text { Management (Percent) }\end{array}$ & [12] \\
\hline 8 & $\begin{array}{l}\text { High-Speed } \\
\text { Internet Providers } \\
\text { for Domestic } \\
\text { Uses }\end{array}$ & MBPS & [8] \\
\hline
\end{tabular}

\subsection{Sustainable Growth Readiness}

International experience shows that integration planning between infrastructure, production, and economic activities with non-economic activities, accompanied by adequate branding will be the success key to achieving the ultimate status of the corridor. In addition to economic infrastructure, corridor access to health, education, social, and cultural facilities must be prepared as part of an integrated corridor development. Therefore, when planning leads to the development of modern corridors, all the facilities that are expected to become machines that can drive faster and sustainable growth along with strong branding need to be properly prepared, synchronised, and widely opened for investment and financing commitments.

\begin{tabular}{cccc}
\multicolumn{2}{c}{ Table $\mathbf{4}$ - Performance Indicators Sustainable Growth Readiness } \\
\hline No & \multicolumn{1}{c}{ Services } & Performance Indicator & $\begin{array}{c}\text { Referenc } \\
\text { es }\end{array}$ \\
\hline 1 & Accessibility to & Ratio University per 1000 & {$[6]$} \\
& University & people & \\
2 & Accessibility to & Ratio of availability of & {$[6,13]$} \\
& RnD and Testing & RnD Facility and Testing & \\
& Laboratory & Laboratory for related & \\
\hline
\end{tabular}


International Journal of Economics, Business, and Accounting Research (IJEBAR)

Peer Reviewed - International Journal

Vol-5, Issue-1, 2021 (IJEBAR)

E-ISSN: 2614-1280 P-ISSN 2622-4771

https://jurnal.stie-aas.ac.id/index.php/IJEBAR

\begin{tabular}{|c|c|c|c|}
\hline & & product & \\
\hline 3 & $\begin{array}{l}\text { Accessibility to } \\
\text { Health Facility }\end{array}$ & $\begin{array}{l}\text { Ratio of Type A Hospital } \\
\text { bed per } 1000 \text { people }\end{array}$ & {$[10,13]$} \\
\hline 4 & $\begin{array}{l}\text { Reuse and Recycled } \\
\text { waste potential }\end{array}$ & $\begin{array}{l}\text { Percentage between } 3 \mathrm{R} \\
\text { Waste Treatment Capacity } \\
\text { and Waste Generation }\end{array}$ & {$[8]$} \\
\hline 5 & Air Pollution Control & $\begin{array}{l}\text { Effective Strategy and } \\
\text { Policy for Air Pollution } \\
\text { Control }\end{array}$ & {$[1,4,15]$} \\
\hline 6 & $\begin{array}{l}\text { Access to Public } \\
\text { Spaces, Sport, } \\
\text { Cultural, Arts, and } \\
\text { Leisure Facility }\end{array}$ & $\begin{array}{l}\text { Accessibility of Integrated } \\
\text { Green Public Space, } \\
\text { stadium, art center, etc }\end{array}$ & {$[12,13]$} \\
\hline
\end{tabular}

\section{Discussion}

The significance of Transport and Logistic Infrastructure in support to the effectiveness of Corridor is apparent. Thirty-one (31) Indicators yielded out of extraction from 11 corridor studies. They consists of $12(38,7 \%)$ indicators in transport-logistic services, $6(19,3 \%)$ that of production support services, $7(22,6 \%)$ that of quality of life support, and $6(19,3 \%)$ indicators to support sustainable growth. Transport and logistics services seems to have double number of indicators comparing other services that share almost even number of indicators. . Since the concept of corridor is based upon transportation infrastructure, it is quite sensible that issues in transport and logistics have been predominantly discussed. This indicates that a corridor would relies most upon supply of transport infrastructure services rather than other infrastructure.

From 12 indicators relevant to transport and logistics, 4 indicators are associated with infrastructure supply, 4 relates to Quality of Service, 2 indicators relates to efficiency, 1 indicator represents utilization, and 1 indicators relates to risks control. Indicators associated with infrastructure supply includes the availability of backbone, alternative-transport mode capacity and the availability of intermodal facility. In relation to operational and quality of services, include handling speed, timeliness, and track and trace services. Indicators relate to efficiency in terms of transport costs, while utilization associates with backbone uses and risks control relates to safety prevention and control. The 12 indicators are likely representing basic transport and logistic services to contribute to Logistic performance index of the respective country.

Corridor has clearly designed for economic development and productivity.

This might bring in question how population can anticipate their need of livings in a corridor. It is interesting that corridor overlooked the need for accommodation of population along the corridor. Except McNeil et al (2010a) there is no other researcher focus their research beyond transport-logistics and production support. Hartman (2013) suggested to include number of production estates to be an indicator for corridor performance. This was the only indicator available beyond transport and logistic services. The other, Prause dan Schroder (2015) and ADB (2012) suggested the availability of policy on air pollution management and control is included as performance indicator for corridor, this, however, this seems also relate to the impact of transport, logistics, and production of the corridor. This shows that study in corridor development predominantly focus upon outcome of corridor in terms of transport and logistic, 
International Journal of Economics, Business, and Accounting Research (IJEBAR)

Peer Reviewed - International Journal

Vol-5, Issue-1, 2021 (IJEBAR)

E-ISSN: 2614-1280 P-ISSN 2622-4771

https://jurnal.stie-aas.ac.id/index.php/IJEBAR

little focus on production support, and mostly unable to answer the need for quality of life support and sustainable growth.

Since corridor program focus upon transport, logistic, and production services, corridor management would expect local services provided by regency or municipal governments could anticipate increases of domestic needs that is attributed to the growing activity in the corridor. This would require planning integration between corridor management and local government to ensure the corridor could provide sufficient spill from their project to the neighboring areas, or otherwise, local governments can take part in providing certain services that might be much more efficient for both production estates and domestic purposes.

\section{Conclusion and Further Works}

\subsection{Conclusion}

The performance of corridor is obviously able to be approached from its infrastructure through a set of infrastructure service performance indicators. This much clearer for a national corridor wherein corridor management refers to national government. In this situation, service standards and regulations are set as national based regulation that is affecting the whole corridors within the country. This also applies to Indonesia Economic Corridor which commenced in 2011 and consisted 6 economic corridors.

In ensuring corridor development, it is imperative to provide comprehensive infrastructure services in 4 areas, including transport and logistics, water supply and sanitation, energy, and bandwidth. These are dedicated as transport and logistics support, production supports, quality of life support, and sustainable growth and risks control to enable a corridor follow development staging from transport corridor to ultimate stage as growth corridor.

There are 31 indicators can be used to enable comprehensive assessment of infrastructure readiness of a corridor. These can also be used to assess stage of development of a corridor and plan for program for the corridor to proceed to the next stage. The 31 indicators consists of 12 indicators for transport and logistic related services, 6 indicators for production support, 7 indicators for quality of life, and 6 indicators for sustainable growth.

\subsection{Further Works}

As it has been emphasized by Kunaka and Carruthers (2014), assessing a corridor performance would need comprehensive assessment of the interaction between performances of infrastructure, services, and corridor institution. This would include assessment upon operational corridor, planning integration, and the availability and compliance toward of relevant standards and regulations. The 31 indicators resulted ini this study are not only applied in assessing operational status of infrastructure corridor, but also an important tools in assessing planning integrations that might indicates level of suitability and supply effectivity of corridor infrastructure. To be able to do such work, it is important to find out the relative importance of the infrastructure services and determine level of infrastructure integration plan of the corridor.

\section{References}

Asian Development Bank. (2012), Transport Efficiency through Logistics Development: Policy Study. Mandaluyong City, Philippines: Asian Development Bank.

Banomyong, R. (2010). Benchmarking Economic Corridors logistics performance: a GMS border crossing observation. World Customs Journal, 4(1), 29-38. 
International Journal of Economics, Business, and Accounting Research (IJEBAR)

Peer Reviewed - International Journal

Vol-5, Issue-1, 2021 (IJEBAR)

E-ISSN: 2614-1280 P-ISSN 2622-4771

https://jurnal.stie-aas.ac.id/index.php/IJEBAR

Government of Indonesia. (2011). Masterplan of Acceleration and Expansion of Indonesia Economic Development 2011-2025. Coordinating Ministry for Economic Affairs, Jakarta.

Hartman, Oliver 2013, Corridor Transport Observatory Guidelines. Working Paper No. 98, November 2013

Havenga, J. H. \& De Bod, A. 2016. Freight corridor performance measurement system: a framework for South Africa. Journal of Transport and Supply Chain Management

Keputusan Menteri Pendidikan Nasional Republik Indonesia Nomor 129a/U/2004 tentang Standar Pelayanan Minimal Bidang Pendidikan - Oktober 2004

Kunaka, C., dan Carruthers, R. (2014). Trade-and-Transport-Corridor-Management-Toolkit. The World Bank. Washington: The World Bank.

McNeil, S., Li, Q., Oswald, M., Gallis, M., Kreh, E., Peterson, Z., Skancke, T. (2010a). Developing an Infrastructure Index - Phase I. Delaware University.

McNeil, S., Oswald, M., dan Ames, D. (2010b). A Case Study of the BOSWASH Transportation Corridor: Observations Based on Historical Analyses., University of Delaware.

Peraturan Menteri Kesehatan tentang Standar Pelayanan Minimal Bidang Kesehatan - Oktober 2016

Peraturan Menteri Negara Perumahan Rakyat Republik Indonesia nomor: Peraturan Menteri Negara 22/PERMEN/M/2008 Tentang Standar Pelayanan Minimal Bidang Perumahan Rakyat daerah provinsi dan daerah kabupaten/kota - Desember 2008

Peraturan Menteri Pekerjaan Umum no 01/prt/M/.2014 tentang Standar Pelayanan Minimal Bidang Pekerjaan Umum dan Penataan Ruang - Februari 2014

Northeast Corridor Commitee (2014). The Northeast Corridor and the American Economy. Downloaded from http://www.nec-commission.com/wpcontent/uploads/2014/02/NEC_american_economy_report.pdf

Nogales, E. G. (2014). Agribusiness and Food Industries Series Making economic corridors work for the agricultural sector. FAO Publications, Rome.

Prause, G., dan Schröder, M. (2015). KPI Building Blocks for Successful Green Transport Corridor Implementation. Transport and Telecommunication, 16(4), 277-287.

Raballand, G., Marteau, J., Kunaka, C., kabanguka, J. dan Hartman, O. (2008). Lesson of Corridor Performance Maesurement. Sub-Saharan Africa transport Policy Program (Discussion Paper No. 7 Regional Integration and Transport - RIT Series). https://www.worldbank.org/afr/sstatp

Reeg, C., (2017) Spatial Development Initiatives-Potentials, Challenges and Policy Lesson with a Specific Outlook for Inclusive Agrocorridors in Sub-Saharan Africa, Report, Deutsches Institut für Entwicklungspolitik 97, Bonn.

Schutte, I. (2005). Maputo Development Corridor: Evaluation of First Phase', Proceedings of the 24th Southern African Conference (SATC 2005), pp.623-631.

Srivastava, P. (2011). Regional Corridors Development in Regional Cooperation | Asian Development Bank (1655-5252 No. 258). Manila.

Stone, S., dan Strutt, A. (2009). Transport infrastructure and trade facilitation in the Greater Mekong Subregion (Asian Development Bank Institute Working Paper No. 130). Tokyo.

$\mathrm{Xu}$, Hangtian dan Li, Zhigang. (2016). High-Speed Railroad and Economic Geography: Evidence from Japan (Asian Development Bank Economics Working Paper Series No.485).

Manila. 